\title{
Pengaruh Kepuasan Kerja dan Pemberian Kompensasi terhadap Kinerja Individu dengan Loyalitas Sebagai Variabel Intervening
}

\author{
Siti Aminah, dan Umar Chadhiq* \\ Fakultas Ekonomi, Universitas Wahid Hasyim \\ *Email: umar_chadhiq@unwahas.ac.id
}

\begin{abstract}
Abstrak
Tujuan penelitian adalah untuk menganalisis dan membuktikan pengaruh kepuasan kerja dan pemberian kompensasi terhadap kinerja individu dengan loyalitas sebagai variabel intervening. Populasi dalam penelitian ini adalah seluruh pegawai PT PLN (Unit Induk Distribusi Jateng dan DIY), sampel pada penelitian ini sebanyak 60 responden. Pengumpulan data penelitian dengan cara penyebaran kuesioner. Teknik pengambilan sampel dalam penelitian ini dengan menggunakan rumus slovin dan data yang diolah menggunakan pendekatan Partial Least Squares Struktural Equation Modeling (SPLSSEM) dengan bantuan bantuan program SmartPLS serta tingkat signifikasi 5\%. Hasil penelitian menunjukkan bahwa (1) Kepuasan berpengaruh positif dan signifikan terhadap loyalitas koefisien jalur 0,4 p-value 0,000 <0,05 (2) Pemberian kompensasi berpengaruh positif dan signifikan terhadap loyalitas koefisien jalur 0,241 p-value 0,023 <0,05, (3) Kepuasan kerja berpengaruh positif dan tidak signifikan terhadap kinerja individu koefisien jalur 0,011 p-value 0,913 > 0,05 (4) Pemberian kompensasi bepengaruh positif dan tidak signifikan terhadap kinerja individu koefisien jalur 0,031 p-value 0,697>0,05 (5) Loyalitas berpengaruh positif dan signifikan terhadap kinerja individu koefisien jalur 0,781 p-value 0,000 <0,05. Nilai $R^{2}$ pada penelitian ini untuk variabel loyalitas (Y1) adalah 0,297 atau 29,7\% yang memiliki arti bahwa presentase besarnya kepuasan kerja (X1) dan pemberian kompensasi (X2) terhadap loyalitas adalah sebesar 29,7\% angka tersebut termasuk dalam kategori moderat, sedangkan sisanya 70,3\% dipengaruhi oleh variabel lain, dan untuk variabel kinerja individu nilai $R^{2}$ sebesar 0,615 atau 61,5\% yang berarti bahwa pengaruh kepuasan kerja dan pemberian kompensasi terhadap kinerja individu sebesar $61,5 \%$ hal ini berarti termasuk dalam kategori kuat, sedangkan sisanya yaitu $38,5 \%$ dijelaskan oleh variabel lain diluar penelitian ini.
\end{abstract}

Kata kunci: Kepuasan kerja, kompensasi, loyalitas, kinerja individu.

\begin{abstract}
The research objective is to analyze and prove the effect of job satisfaction and compensation on individual performance with loyalty as an intervening variable. The population in this study were all employees of PT PLN (Central Java and DIY Distribution Main Unit), the sample in this study were 60 respondents. Collecting research data by distributing questionnaires. The sampling technique in this study used the Slovin formula and the data were processed using the Partial Least Squares Structural Equation Modeling (SPLS-SEM) approach with the help of the SmartPLS program and a significance level of $5 \%$. The results showed that (1) Satisfaction has a positive and significant effect on pathway coefficient loyalty 0.4 p-value $0.000<0.05$ (2) Compensation has a positive and significant effect on loyalty path coefficient 0.241 p-value $0.023<0.05$, (3) Job satisfaction has a positive and insignificant effect on individual performance path coefficient $0.011 \mathrm{p}$ value 0.913>0.05 (4) Compensation has a positive and insignificant effect on individual performance path coefficient 0.031 p-value 0.697> 0.05 (5) Loyalty has a positive and significant effect on individual performance, the path coefficient is 0.781 p-value 0.000 $<0.05$. The value of $R^{2}$ in this study for the loyalty variable (Y1) is 0.297 or $29.7 \%$ which means that the percentage of job satisfaction (X1) and compensation (X2) for loyalty is $29.7 \%$, this figure is included in the moderate category, while the remaining $70.3 \%$ is influenced by other variables, and for individual performance variables the value of $R^{2}$ is 0.615 or $61.5 \%$, which means that the percentage of the influence of job satisfaction and compensation on individual performance is $61.5 \%$, this means it is included in the category. strong, while the remaining $38.5 \%$ is explained by other variables outside of this study.
\end{abstract}

Keywords: Job satisfaction, compensation, loyalty, individual performance. 


\section{PENDAHULUAN}

Seiring dengan perubahan globalisasi saat ini dan dalam kondisi masyarakat sekarang, seringkali kita menemukan beberapa permasalahan yang menyebabkan sebuah instansi/perusahaan mengalami kegagalan dalam mencapai tujuan, baik karena ketidak mampuannya bersaing dan beradaptasi dengan kemajuan teknologi pada saat ini maupun karena rendahnya kinerja dari sumber daya manusia itu sendiri dalam instansi/perusahaan tersebut, padahal seperti yang kita semua ketahui bahwa manusia merupakan faktor yang paling penting dalam berhasil tidaknya sebuah instansi/perusahaan mencapai tujuan.

Sumber daya manusia dituntut untuk dapat memperlihatkan hasil yang baik di dalam perusahaan, sumber daya manusia merupakan unsur yang terpenting. Tanpa peran manusia meskipun berbagai faktor yang dibutuhkan itu telah tersedia, instansi/perusahaan tidak akan berjalan. Karena manusia merupakan penggerak dan penentu jalannya suatu organisasi, oleh karena itu hendaknya dari instansi/perusahaan itu sendiri memberikan arahan yang positif demi tercapainya tujuan. Keberhasilan suatu organisasi dalam mencapai tujuan organisasi ditentukan oleh kinerja karyawan. Kemampuan karyawan mengerjakan pekerjaan yang menjadi tanggung jawabnya menjadi tolok ukur pencapaian tujuan organisasi. Karyawan dalam mencapai tujuan organisasi mempunyai tanggung jawab yang harus diselesaikan oleh karyawan yang diberi tanggung jawab untuk menyelesaikannya.

Menurut Mangkunegara (2008) kinerja karyawan adalah tingkat pencapaian hasil atas pelaksanaan tugas tertentu seorang karyawan. Kinerja adalah hasil atau tingkat keberhasilan seseorang secara keseluruhan selama periode tertentu di dalam melaksanakan tugas dibandingkan dengan berbagai kemungkinan, seperti standar hasil kerja, target atau sasaran atau kriteria yang telah ditentukan terlebih dahulu dan telah disepakati bersama.(Rivai \&Sagala, 2013).

Kinerja pegawai dalam organisasi mengarah pada kemampuan pegawai dalam melaksanakan keseluruhan tugas-tugas yang menjadi tanggungjawabnya. Kinerja seorang pegawai dikatakan baik apabila ia memiliki motivasi yang tinggi, dapat menyelesaikan tugas yang diberikan tepat pada waktunya. Selalu memberikan kontribusi dan memiliki sikap dan perilaku yang baik sesuai standar kerja yang telah ditentukan baik oleh organisasi maupun nilai-nilai yang berlaku dalam lingkungan ia bekerja. Kinerja dapat dipengaruhi beberapa faktor misalnya kepuasan kerja. Menurut Abdurrahmat (2006) kepuasan kerja merupakan suatu bentuk sikap emosional yang menyenangkan dan mencintai pekerjaan yang digelutinya. Kepuasan kerja dalam pekerjaan ialah kepuasan kerja yang dapat dinikmati dalam pekerjaan dengan mendapatkan hasil dari pencapaian tujuan kerja, penempatan, perilaku, dan suasana lingkungan kerja yang baik.

Kepuasan kerja merupakan factor positif yang ditunjukkan oleh karyawan terhadap pekerjaannya, sehingga karyawan dapat bekerja dengan senang hati tanpa merasa terbebani dengan pekerjaan tersebut dan memberikan hasil yang optimal bagi perusahaan.Menurut Malayu S.P Hasibuan (2008) kepuasan adalah sikap emosional yang menyenangkan dan mencintai pekerjaannya. Sikap ini dicerminkan oleh moral kerja, kedisiplinan, dan prestasi kerja. Pekerjaan yang memberikan kepuasan kerja bagi pelakunya ialah pekerjaan yang dirasa menyenangakan untuk dikerjakan (Supriyanto \& Machfudz, 2010). Sebaliknya, pekerjaan yang tidak menyenangkan untuk dikerjakan merupakan indikator dari rasa ketidakpuasan dalam bekerja (Bangun, 2012). Kepuasan kerja juga dipengaruhi dari beberapa dimensi misal pemberian kompensasi yang cukup.

Menurut Nawawi (2005) yang berpendapat bahwa kompensasi bagi organisasi/perusahaan berarti penghargaan/ganjaran pada para pekerja yang telah memberikan kontribusi dalam mewujudkan tujuannya melalui kegiatan yang disebut bekerja.Kompensasi adalah aspek penting bagi pegawai yang bekerja dalam suatu organisasi. Adapun pengertian menurut Yuniarsih (2011), bahwa kompensasi pegawai berarti semua bentuk penggajian atau ganjaran yang mengalir kepada pegawai atau timbul dari kepegawaian mereka. Kompensasi didefinisikan oleh Sastrohadiwiryo (2002) adalah imbalan jasa atau balas jasa yang diberikan oleh perusahaan/organisasi kepada para tenaga kerja, karena tenaga kerja tersebut telah memberikan sumbangan tenaga dan pikiran demi kemajuan perusahaan guna mencapai tujuan yang di tetapkan. Kompensasi merupakan sesuatu yang diterima oleh karyawan sebagai imbalan jasa mereka terhadap perusahaan. Seorang karyawan menghargai sebuah kerja keras dan akan menunjukkan loyalitasnya kepada perusahaan. Menurut 
Hani Handoko (2004) berpendapat bahwa kompensasi mencerminkan ukuran karya mereka di antara para karyawan itu sendiri, keluarga dan masyarakat.

Loyalitas kerja atau kesetiaan merupakan salah satu unsur yang digunakan dalam penilaian karyawan yang mencakup kesetiaan terhadap pekerjaannya, jabatannya dan organisasi. Menurut Hasibuan, (2003) kesetiaan ini dicerminkan oleh kesediaan karyawan menjaga dan membela organisasi di dalam maupun di luar pekerjaan dari rongrongan orang yang tidak bertanggungjawab.Sedangkan menurut Sudimin (2003) berpendapat bahwa loyalitas adalah kesediaan karyawan dengan seluruh kemampuan, keterampilan, pikiran, dan waktu untuk ikut serta mencapai tujuan organisasi dan menyimpan rahasia organisasi serta tidak melakukan tindakan tindakan yang merugikan organisasi selama orang itu masih berstatus sebagai karyawan. Kemudian menurut Saydam (2005) loyalitas merupakan sikap mental karyawan yang ditunjukkan pada keberadaan perusahaan.

Sumber daya manusia peranan yang sangat besar dalam perusahaan, maka banyak perusahaan yang semakin menyadari bahwa sumberdaya manusia sebagai unsur yang memberikan keunggulan bersaing. Untuk mendapatkan kualitas karyawan yang tinggi, perusahaan harus benarbenar memperhatikan karyawannya sehingga serasa mendapatkan perhatian dari perusahaan dan tidak merasa terabaikan.

Memberikan fasilitas yang dibutuhkan diharapkan karyawan mampu meningkatkan keunggulan atau kualitas dari karyawan perusahaan, misalnya pelatihan, teknologi spesialisasi kerja, fasilitas yang lengkap dan layak pakai, kenyamanan dan keamanan lingkungan kerja, serta berbagai fasilitas yang dapat menunjang seluruh aktivitas pekerjaan dari setiap karyawan.

Peningkatan kinerja karyawan dapat dikatakan bahwa karyawan merasa puas sehingga berdampak bagi kemajuan perusahaan serta loyalitas karyawan terhadap perusahaan semakin besar. Karyawan yang memiliki sikap perjuangan, pengabdian, disiplin, dan kemampuan profesional sangat mungkin mempunyai prestasi kerja dalam melaksanakan tugas sehingga lebih berdaya guna dan berhasil guna. Karyawan yang profesional dapat diartikan sebagai sebuah pandangan untuk selalu berpikir, kerja keras, bekerja sepenuh waktu, disiplin, jujur, loyalitas tinggi, dan penuh dedikasi demi untuk keberhasilan pekerjaannya.

Reformasi pengelolaan Badan Usaha Milik Negara (BUMN) telah membawa arah pengembangan karir tidak lagi didasarkan oleh kepentingan nepotisasi dan transaksional, meningkatkan kinerja pegawai merupakan hal serius dalam penentuan arah perusahaan di masa depan dengan itu sudah sewajarnya peningkatan kinerja didasarkan pada prestasi kerja karyawan. Sebagaimana diketahui, PT PLN (Persero) merupakan badan usaha milik negara yang bergerak dalam industri tenaga listrikwilayah distribusi tenaga listrik mencakup wilayah Jawa Tengah dan DIY.Penelitian ini dilaksanakan di PT PLN (Persero) Unit Induk Distribusi Jawa Tengah dan DIYogyakarta berkantor di Semarang.Kinerja karyawan menjadi perhatian utama, karena kualitas kinerja karyawan sangat berhubungan erat dengan kualitas perusahaan. Kinerja dinyatakan baik dan sukses jika tujuan yang diinginkan dapat tercapai dengan baik Menurut Sulistiyani dan Rosidah (2003) mengemukakan bahwan kinerja merupakan catatan outcome yang dihasilkan dari fungsi pegawai tertentu atau kegiatan yang dilakukan selama periode waktu tertentu.

Penelitian seperti ini telah banyak dilakukan sebelumnya, Anwar Basalamah (2012) tentang Pengaruh Kepuasan Kerja Terhadap Loyalitas Staf Reception Pada Hotel X di Madiun Jawa Timur, hasil menunjukkan bahwa tingkat kepuasan kerja pada staf reception hotel akan dapat berkesinambungan dengan loyalitas kerjanya, maka kepuasan kerja berpengaruh signifikan terhadap loyalitas karyawan. Namun bertolak belakangan dengan penelitian yang diteliti oleh Indra Ardianto (2016) yang berjudul Pengaruh Beban Kerja dan Lingkungan Kerja Terhadap Loyalitas Karyawan di PD. BPR Bank Daerah Karang Anyar. Hasil penelitian tidak mencakup atau tidak berpengaruh signifikan kepuasan kerja sebagai variabel yang dapat mempengaruhi loyalitasa karyawan.

Adapun penelitian mengenai Pengaruh Kompensasi Terhadap Loyalitas Karyawan PT. Putera Lautan Kumala Lines Samarinda. Oleh Rahmadana Safitri (2015). Kompensasi berpengaruh signifikan dan positif terhadap loyalitas karyawan, dimana dalam penelitian ini diketahui bahwa kompensasi memberikan pengaruh sebesar 13,6\% terhadap loyalitas karyawan. Sedangkan menurut Filian Mufcha Ihwana (2017) yang mengangkat judul tentang Pengaruh Kompensasi dan Motivasi Kerja Terhadap Loyalitas Perawat Magang pada Rumah Sakit Lanud Iswahjudi Maospati 
Kabupaten Magetan. Hasilnya menunjukkan bahwa secara parsial kompensasi tidak berpengaruh signifikan terhadap loyalitas karyawan.

Penelitian yang dilakukan oleh Ni Made Rima Pranita (2016) yang berjudul Pengaruh Loyalitas Pegawai Terhadap Kinerja Lembaga Perkreditan Desa, menunjukkan bahwa hasil kesimpulan yang didapat bahwa loyalitas pegawai berpengaruh positif dan signifikan terhadap kinerja karyawan. Adapula penelitian menurut Andrew M.C. Mamesah (2016), Pengaruh Lingkungan Kerja, Disiplin Kerja, dan Loyalitas Kerja Terhadap Kinerja Karyawan Pada LPP dengan hasil yang menunjukkan bahwa lingkungan kerja, disiplin kerja, dan loyalitas kerja secara simultan dan parsial berpengaruh signifikan terhadap kineja karyawan.

\section{Kinerja Individu}

Menurut Simamora (2002) kinerja merupakan hasil kerja yang dapat dicapai oleh seseorang atau sekelompok orang dalam suatu organisasi, sesuai dengan wewenang dan tanggung jawab masing masing, dalam rangka upayamencapai tujuan organisasi bersangkutan secara legal, tidak melanggar hukum dan sesuai dengan moral maupun etika. Menurut Bangun (2012), salah satu sumber daya organisasi yang memiliki peran penting dalam mencapi tujuannya adalah sumber daya manusia. Oleh karena itu, maka perlu adanya perhatian khusus agar kinerja karyawan dapat maksimal. Kinerja karyawan yang menurun tentu akan sangat mempengaruhi stabilitas perusahaan. Dimana karyawan dengan kinerja yang buruk, semangat kerja yang kurang akan membuat target perusahaan menjadi tidak tercapai sehingga perusahaan akan sulit untuk bersaing dengan perusahaan lain dan pada akhirnya dapat juga mengalami kebangkrutan jika tidak segera diberikan solusi yang tepat untuk menghadapi masalah kinerja tersebut.

Standar kerja yang baik harus realisstis, dapat diukur dan mudah dipahami dengan jelas sehingga bermanfaat baik bagi organisasi maupun para karyawan (Abdullah, 2014). Terdapat langkah-langkah yang dapat digunakan untuk mengukur kinerja individu, misalnya adalah dengan menggunakan (1) kualitas, (2) kuantitas, (3) ketepatan waktu, (4) efektivitas, (5) kemandirian, dan (6) komitmen kerja (Robbins, 2006).

\section{Kepuasan Kerja}

Menurut Malayu S.P Hasibuan (2008) Kepuasan adalah sikap emosional yang menyenangkan dan mencintai pekerjaannya. Sikap ini dicerminkan oleh moral kerja, kedisiplinan, dan prestasi kerja. Pekerjaan yang memberikan kepuasan kerja bagi pelakunya ialah pekerjaan yang dirasa menyenangakan untuk dikerjakan (Supriyanto \& Machfudz, 2010). Sebaliknya, pekerjaan yang tidak menyenangkan untuk dikerjakan merupakan indikator dari rasa ketidakpuasan dalam bekerja (Bangun, 2012).

Menurut Achmad (2010), kepuasan kerja difungsikan untuk dapat meningkatkan semangat kerja karyawan, meningkatkan produktivitas, menurunkan semangat tingkat absensi, meningkatkan produktivitas, menurunkan tingkat absensi, meningkatkan loyalitas karyawan dan mempertahankan karyawan untuk tetap bekerja di suatu perusahaan. Karyawan yang mendapatkan kepuasan kerjanya ialah karyawan yang memiliki tingkat kehadiran dan perputaran kera yang baik, pasif dalam serikat kerja, dan memiliki prestasi kerja yang lebih baik dari karyawan lainnya.

Selanjutnya menurut Supriyanto dan Machfud (2010) menyatakan terdapat beberapa jumlah indikator yang dapat digunakan untuk mengukur kepuasan kerja. Indikator kepuasan kerja tesebut adalah; (1) kepuasan finansial, (2) kepuasan fisik, (3) kepuasan sosial, dan (4) kepuasan psikologi.

\section{Pemberian Kompensasi}

Kompensasi adalah aspek penting bagi pegawai yang bekerja dalam suatu organisasi. Nawawi (2005), berpendapat bahwa kompensasi bagi organisasi/perusahaan berarti penghargaan/ganjaran pada para pekerja yang telah memberikan kontribusi dalam mewujudkan tujuannya, melalui kegiatan yang disebut bekerja. Adapun pengertian menurut Yuniarsih (2011), bahwa kompensasi pegawai berarti semua bentuk penggajian atau ganjaran yang mengalir kepada pegawai atau timbul dari kepegawaian mereka. Kompensasi didefinisikan oleh Sastrohadiwiryo (2002) adalah imbalan jasa atau balas jasa yang diberikan oleh perusahaan/organisasi kepada para 
tenaga kerja, karena tenaga kerja tersebut telah memberikan sumbangan tenaga dan pikiran demi kemajuan perusahaan guna mencapai tujuan yang di tetapkan.

Menurut Veithzal Rivai (2011) terdapat 2 (dua) indikator yang dapat mengukur suatu pemberian kompensasi di suatu perusahaan, yaitu; (1) kompensasi finansial langsung dan (2) kompensasi finansial tidak langsung.

\section{Loyalitas}

Sudimin (2003) berpendapat bahwa loyalitas adalah kesediaan karyawan dengan seluruh kemampuan, keterampilan, pikiran, dan waktu untuk ikut serta mencapai tujuan organisasi dan menyimpan rahasia organisasi serta tidak melakukan tindakan - tindakan yang merugikan organisasi selama orang itu masih berstatus sebagai karyawan. Sedangkan menurut Saydam (2005) loyalitas merupakan sikap mental karyawan yang ditunjukkan pada keberadaan perusahaan.Menutur Fathoni (2006) adalah usaha karyawan dalam membela perusahaan, dengan menunjukan bahwa karyawan tersebut berperan aktif terhadap perusahaannya.

Dari beberapa definisi di atas maka dapat disimpulkan bahwa loyalitas kerja adalah kesetiaan, pengabdian, ketaatan, dan ketulusan dalam melaksanakan tugas - tugas yang diakhiri dengan hasil yang dapat dinikmati dan bersangkutan dengan indentifikasi karyawan terhadap organisasi.Menurut Marpaung (2012) mengemukakan loyalitas adalah kepatuhan dan kesediaan karyawan yang diukur dalam empat indikator sebagai berikut: (1) berkair diperusahaan, (2) mengenal perusahaan, (3) kebanggaan sebagai bagian dari perusahaan, dan (4) disiplin jam kerja.

\section{METODE PENELITIAN}

Sampel pada penelitian ini berjumlah 60 responden dari seluruh pegawai PT PLN (Persero) Unit Induk Distribusi Jawa Tengah dan D.I.Yogyakarta, tekik pengambilan sampel menggunakan rumus slovin. Data dikumpulkan dikumpulkan menggunakan kuesioner yang disebarkan kepada karyawan sebanyak 100 kuesioner, namun kuesioner yang dikembalikan sebanyak 60 kuesioner. Alat uji statistik yang digunakan pada penelitian ini adalah Smart PLS dengan analisis SEM. Jumlah kuesioner pada penelitian ini adalah sebagai berikut:

1. Kepuasan keja diukur menggunakan 4 item indikator dari Supriyanto \& Machfudz (2010).

2. Pemberian kompensasi diukur menggunakan 2 indikator dari Veithzal Rivai (2011:357).

3. Loyalitas karyawan diukur menggunakan 4 indikator dari Marpaung (2012).

4. Kinerja individu diukur menggunakan 6 indikator dari Robbins (2006).

Untuk jawaban kuesioner menggunakan Skala Likert yaitu 1-5 (1: sangat tidak setuju; 2:tidak setuju; 3: kurang setuju; 4: setuju; 5: sangat setuju) digunakan untuk mengukur semua item pada penelitian ini.

\section{Model Konseptual Penelitian}

Menurut tinjauan literatur terdahulu, variabel dalam penelitian ini dapat dihubungkan dan disajikan dalam Gambar 1. Dalam model ini kinerja Individu (Y2) merupakan variabel dependen, kepuasan kerja (X1) dan pemberian kompensasi (X2) merupakan variabel independen, dan loyalitas (Y1) merupakan variabel intervening.

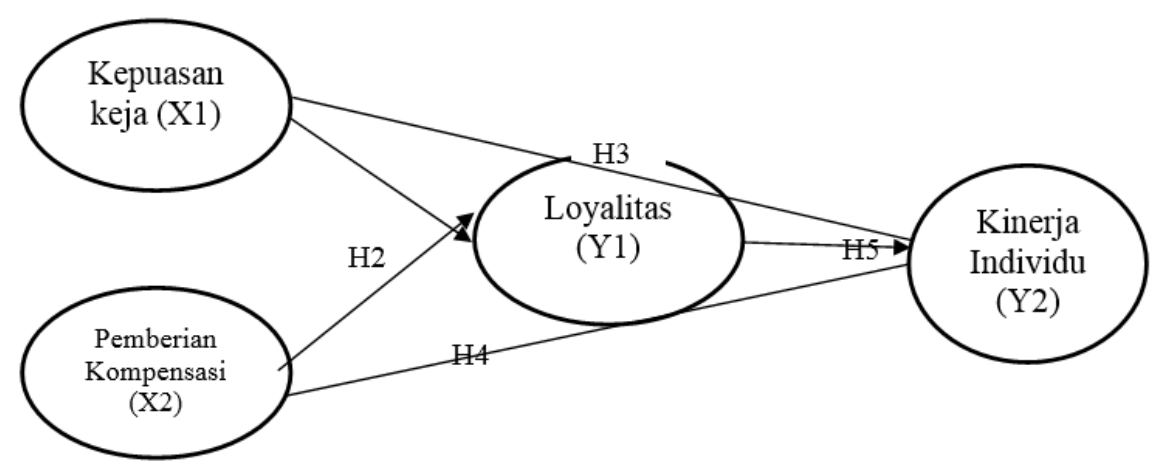

Gambar 1. Model Penelitian 
Kepuasan kerja berpengaruh positif dan signifikan terhadap loyalitas karyawan. Dapat diartikan bahwa loyalitas merupakan hal yang penting bagi perusahaan atau organisasi (Putu Meidita Larastrin,2019).

\section{Hal: Kepuasan kerja berpengaruh positif dan signifikan terhadan loyalitas karyawan}

Menurut Rahmadana Safitri (2015) memberikan bukti bahwa kompensasi terbukti berpengaruh positif dan signifikan terhadap loyalitas karyawan. Dapat diartikan bahwa loyalitas merupakan hal yang penting bagi perusahaan atau organisasi.Karyawan dituntut untuk mampu menyelesaikan tugas dan tanggung jawabnya secara efektif dan efisien.Dalam penelitian ini, yang dimaksud dengan kompensasi merupakan hal penting yang merupakan dorongan atau motivasi utama seorang karyawan untuk bekerja. Semakin baik kompensasi yang diberikan peusahaan, maka akan cenderung berpengaruh terhadap meningkatnya loyalitas karyawan.

Ha2: Pemberian kompensasi berpengaruh positif dan signifikan terhadap loyalitas karyawan.

Menurut Achmad (2010), kepuasan kerja difungsikan untuk dapat meningkatkan semangat kerja karyawan, meningkatkan produktivitas, meningkatkan produktivitas, meningkatkan loyalitas karyawan dan mempertahankan karyawan untuk tetap bekerja di suatu perusahaan. Karyawan yang mendapatkan kepuasan kerjanya ialah karyawan yang memiliki tingkat kehadiran dan perputaran kerja yang baik, pasif dalam serikat kerja, dan memiliki prestasi kerja yang lebih baik dari karyawan lainnya. penelitian yang dilakukan oleh Agus Tunggul Saputra (2016) menyatakan bahwa kepuasan kerja berpengaruh positif signifikan terhadap kinerja individu.

\section{Ha3: Kepuasan kerja berupengaruh positif signifikan terhadap kinerja individu.}

Penelitian yang dilakukan oleh Endrick Leonardo dan Fransisca Andreani (2015) yaitu terdapat pengaruh positif signifikan pemberian kompensasi terhadap kinerja individu. Semakin baik kompensasi yang diberikan peusahaan, maka akan cenderung berpengaruh terhadap meningkatnya kinerjaindividu.

\section{Ha4: pembeian kompensasi berpengaruh positif dan signifikan terhada kinerja indinidu}

Dalam penelitian ini, loyalitas kepada pekerjaan tercermin pada sikap karyawan yang mencurahkan kemampuan dan keahlian yang dimiliki, melaksanakan tugas dengan tanggung jawab, disiplin serta jujur dalam bekerja. Sikap karyawan sebagai bagian dari perusahaan yang paling peting adalah loyal. Sikap ini diantaranya tercermin dari terciptanya suasana yang menyenangkan dan mendukung ditempat kerja, menjaga citra perusahaan dan adanya kesediaan untuk bekerja dalam jangka waktu yang lebih panjang.Agus Tunggal Saputra dkk (2016), yang menyatakan bahwa loyalitas karyawan secara positif dan signifikan berpengaruh terhadap kinerja karyawan.

Ha5: loyalitas karyawan berpengaruh positif signifikan terhadap kinerja individu

\section{HASIL DAN PEMBAHASAN \\ Data Deskriptif}

Data deskriptif mengambarkan keadaan dan kondisi responden pada penelitian ini sebagai informasi tambahan untuk memahami hasil penelitian. Data deskriptif dapat diketahui dengan melihat karakteristik responden.

Adapun gambaran umum profil seluruh responden berdasarkan jenis kelamin dalam penelitian ini dominan perempuan sebesar 48 orang sedangkan laki-laki 12 orang. Berdasarkan usia responden didominasi oleh pegawai yang berusia kurang dari 25 sebanyak 9 orang, usia 22-35 tahun sebanyak 15 orang, usia 36-45 tahun sebanyak 25 orang, usia 46-55 tahun sebanyak 11 orang. Berdasarkan pendidikan didominasi oleh berpendidikan SMA/sederajat yaitu sebanyak 12 
orang, Diploma (D3) yaitu sebanyak 18 orang, S1 sebanyak 28 orang, dan S2 sebanyak 2 orang. Berdasarkan lama kerja didominasi kerja antara 11-15 tahun sebanyak 30 orang, lama kerja 1-5 tahun sebanyak 11 orang, lama kerja 6-10 tahun sebanyak 15 orang, dan lama kerja lebih dari 15 tahun sebanyak 4 orang.

\section{Pengaruh Antar Variabel}

Pada Tabel 1 menjelaskan pengaruh antar variabel untuk mengetahui sejauh mana pengaruh antar variabel tersebut saling berhubungan dan untuk mengetahui hipotesis yang diajukan diterima atau tidak.

Tabel 1 Pengaruh Antar Variabel

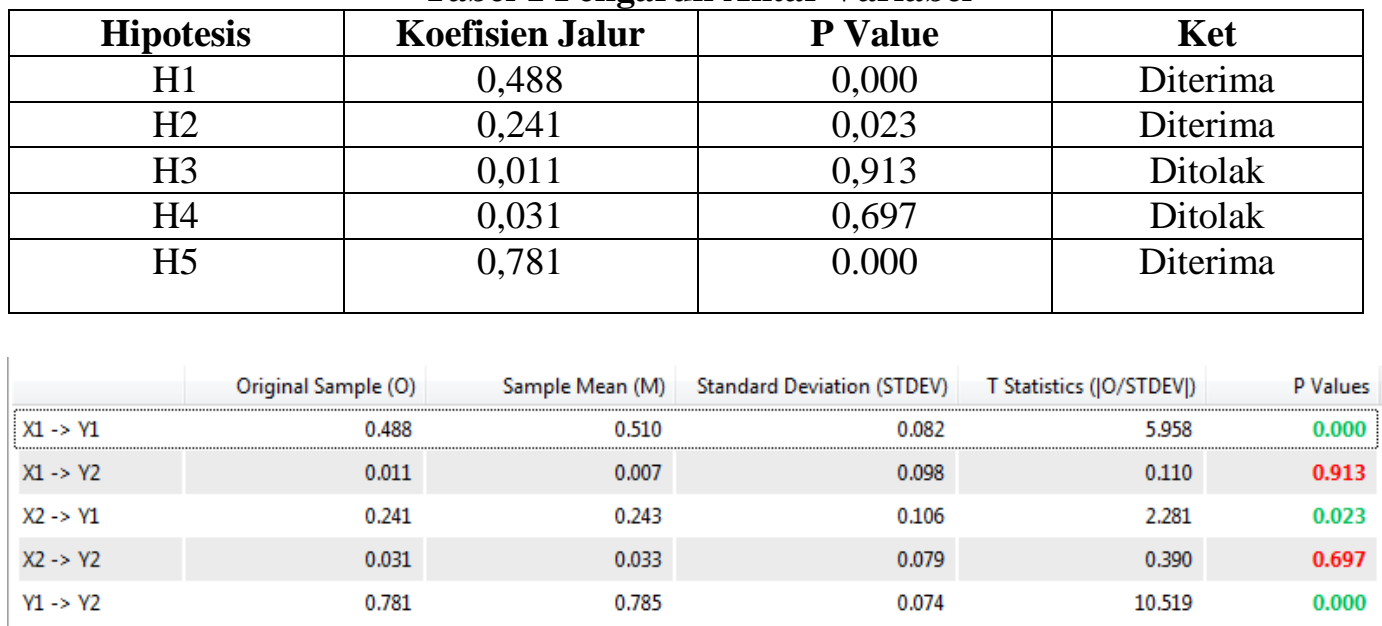

Sumber: Output SmartPLS (Data Diolah, 2020)

Dari Tabel 1 dapat disimpulkan bahwa H1, H2, dan H5 hipotesis diterima dan menunjukkan pengaruh yang signifikan hal tersebut dapat dilihat dari nilai P-Value menyatakan bahwa nilai PValue $<0,05$. Sedangkan H3 dan H4 dipotesis ditolak menunjukkan pengaruh tidak signifikan hal tersebut dapat dilihat dari nilai P-Value menyatakan bahwa nilai P-Value $>0,05$.

Pada Tabel 2 menjelaskan pengaruh tidak lansung antar variabel untuk mengetahui sejauh mana hubungan pengaruh tidak langsung tersebut saling berhubungan.

Tabel 2 Pengaruh Tidak Langsung

\begin{tabular}{|c|c|c|c|c|c|c|}
\hline \multirow[t]{3}{*}{ VARIABEL } & \multicolumn{5}{|c|}{ VARIABEL } & \multirow[t]{3}{*}{ KESIMPULAN } \\
\hline & \multicolumn{2}{|c|}{ DE } & IE & \multicolumn{2}{|c|}{ TE } & \\
\hline & Y1 & $\mathbf{Y 2}$ & Y2 & $\mathbf{Y 2}$ & Sig. & \\
\hline (1) & (2) & (3) & (4) & $(5)=(3+4)$ & (6) & (7) \\
\hline $\mathrm{X} 1$ & 0,448 & 0,011 & 0,382 & 0,393 & 0,000 & $\begin{array}{c}\text { Intervening Berperan } \\
\text { dan Signifikan }\end{array}$ \\
\hline $\mathrm{X} 2$ & 0,241 & 0,031 & 0,188 & 0,219 & 0,015 & $\begin{array}{c}\text { Intervening Berperan } \\
\text { dan Signifikan }\end{array}$ \\
\hline Y1 & & 0,781 & & & & \\
\hline \multicolumn{7}{|c|}{$\mathrm{DE}=$ Direct Effect $;$ IE $=$ Indirect Effect $;$ TE $=$ Total Effect } \\
\hline
\end{tabular}




\section{Specific Indirect Effects}

\begin{tabular}{|c|c|c|c|c|c|c|c|}
\hline \multirow[t]{2}{*}{ 贯 } & \multicolumn{2}{|c|}{ Mean, STDEV, T-Values, P-Va... } & \multicolumn{2}{|c|}{ Confidence Intervals } & \multicolumn{2}{|c|}{ Confidence Intervals Bias C... } & \multirow{2}{*}{$\begin{array}{c}\text { Samples } \\
\text { P Values }\end{array}$} \\
\hline & & Original Sampl... & - Sample Mean (... & \multicolumn{2}{|c|}{ Standard Devia... } & T Statistics $(\mid \mathrm{O} \ldots$ & \\
\hline $\mathrm{X} 1$ & $\rightarrow \mathrm{Y} 1 \rightarrow \mathrm{Y} 2$ & 0.382 & 0.398 & & 0.077 & 4.942 & 0.000 \\
\hline$X 2$ & $\rightarrow Y_{1}->Y_{2}$ & 0.188 & 0.191 & & 0.077 & 2.436 & 0.015 \\
\hline
\end{tabular}

Sumber: Output SmartPLS (Data diolah, 2020)

Berdasarkan dari pengaruh langsung, pengaruh tidak langsung dan pengaruh total maka dapat diketahui bahwa intervening berperan pada X1 atau variabel kepuasan kerja terhadap variabel kinerja melalui loyalitas (Y1) berpengaruh signifikan yaitu dengan koefisien parameter sebesar 0,382 denga $\mathrm{p}$-value $0,000<0,05$. Intervening berperan pada $\mathrm{X} 2$ atau variabel pemberian kompensasi terhadapvariabel kinerja berpengaruh signifikan melalui variabel loyalitas (Y1) yaitu dengan koefisien jalur 0, 188 dengan p-value $0,015<0,05$.

Hasil pengujian pengaruh kepuasan kerja (X1) terhadap loyalitas (Y1) menggunakan software SmartPLS menghasilkan koefisien jalur sebesar 0,488 dengan p-value sebesar 0,000 $(0,000<0,05)$. Hasil ini menunjukkan bahwa kepuasan kerja berpengaruh positif dan signifikan terhadap loyalitas. Kepuasan kerja akan terbentuk apabila adanya tingkat kepuasan berdasarkan faktor-faktor yang mempengaruhi, dalam penelitian ini yang paling memberikan kontribusi adalah indikator kepuasan fisik. Kenyamanan kondisi kerja, pembagian kelompok kerja yang sesuai dan fasilitas yang disediakan dapat meningkatkan loyalitas pegawai. Hasil penelitian ini mendukung penelitian yang dilakukan oleh Agus Tunggul Saputra (2016) yang menunjukkan bahwa kepuasan kerja berpengaruh positif dan signifikan terhadap loyalitas.

Kemudian hasil pengujian pengaruh pemberian kompensasi (X2) terhadap loyalitas (Y1) menggunakan software SmartPLS menghasilkan koefisien jalur sebesar 0,241 dengan $p$-value sebesar $0,023(0,023<0,05)$. Hasil ini menunjukkan bahwa pemberian kompensasi berpengaruh positif dan signifikan terhadap loyalitas. Pemberian kompensasi secara keseluruhan memberikan kontribusi paling besar sebagai faktor yang mempengaruhi loyalitas, hal tersebut ditunjukkan dengan hasil path koefisien sebesar 0,947. Berdasarkan hasil tersebut mengindikasikan bahwa para pegawai akan meningkatkan loyalitas apabila kompensasi yang diberikan sesuai dengan pekerjaan yang dilakukan. Hasil penelitian ini mendukung atau sejalan dengan penelitian yang dilakukan oleh Rahmadana Safitri (2015) yang menjunkukkan bahwa pemberian kompensasi berpengaruh positif dan signifikan terhadap loyalitas pegawai.

Sedangkan hasil pengujian pengaruh kepuasan kerja (X1) terhadap kinerja individu (Y2) menggunakan software SmartPLS menghasilkan koefisien jalur sebesar 0,011 dengan p-value sebesar $0,913(0,913>0,05)$. Hasil ini menunjukkan bahwa kepuasan kerja berpengaruh positif namun tidak signifikan terhadap kinerja individu. Dalam hal ini indikator-indikator kepuasan kerja yaitu kepuasan finansial, kepuasan sosisal serta kepuasan psikologi ternyata belum dapat menunjukkan tingkat pengaruh kepuasan kerja terhadap kinerja individu itu sendiri. Berdasarkan hasil penelitian ini tidak sejalan dengan penelitian yang dilakukan oleh Agus Tunggul Saputra (2016) yang menyatakan adanya pengaruh positif dan signifikan terhadap kinerja individu.

Setelah itu, hasil pengujian pemberian kompensasi (X2) terhadap kinerja individu (Y2) menggunakan software SmartPLS menghasilkan koefisien jalur 0,031 dengan p-value sebesar $0,697(0,697>0,05)$. Hasil ini menunjukkan bahwa pemberian kompensasi berpengaruh positif namun tidak signifikan terhadap kinerja individu. Pemberian kompensasi belum mampu memberikan kontribusi dalam peningkatan kinerja individu, namun dalam penelitian ini kinerja individu dapat meningkat apabila terbentuk rasa loyal terhadap pekerjaan yang dilakukan melalui pemberian kompensasi. Hasil penelitian ini mendukung penelitian yang dilakukan oleh Endrick Leonardo dan Fransisca Andreani (2015) bahwa pemberian kompensasi berpengaruh positif namun tidak signifikan terhadap kinerja individu.

Terakhir, hasil pengujian pemberian kompensasi (Y1) terhadap kinerja individu (Y2) menggunakan software SmartPLS menghasilkan koefisien jalur 0,781 dengan p-value sebesar 
$0,000(0,000<0,05)$. Hasil ini menunjukkan bahwa loyalitas berpengaruh positif dan signifikan terhadap kinerja individu.Dalam hal ini tingkat loyalitas pegawai mencerminkan seberapa baik performa individu yang diberikan kepada perusahaan. Loyalitas memberikan umpan balik atau respon bagaimana sikap seseorang terhadap pekerjaannya, hasil penelitian ini loyalitas menunjukkan kontribusi yang tinggi dalam meningkatkan kinerja individu. Dengan diterimanya hipotesis 5, hasil penelitian ini konsisten dengan penelitian yang dilakukan oleh Agus Tunggal Saputra dkk (2016), yang menyatakan bahwa loyalitas karyawan secara positif dan signifikan berpengaruh terhadap kinerja karyawan.

\section{KESIMPULAN DAN SARAN}

Berdasarkan hasil analisis data yang diperoleh melalui kuesioner yang disebarkan kepada pegawai PT PLN (Persero) Unit Induk Distribusi Jawa Tengah dan D.I.Yogyakarta dapat disimpulkan bahwa kepuasan kerja berpengaruh terhadap loyalitas, pemberian kompensasi berpengatuh tehadap loyalitas, kepuasan kerja dan pemberian kompensasi tidak berpengaruh terhadap kinerja individu, dan loyalitas karyawan berpengaruh terhadap kinerja individu.

Pada penelitian ini peniliti menyarankan beberapa hal untuk perusahaan diantaranya (1) untuk variabel kepuasan kerja, hendaknya selalu memberikan dukungan, motivasi dan menjalin komunikasi yang harmonis dengan para karyawan, hal ini dapat dilakukan melalui kegiatan gathering dan seminar, sehingga para karyawan merasa mendapat perhatian dari atasan, sehingga menumbuhkan rasa sosial yang tinggi antar pegawai. (2) pada variabel pemberian kompensasi, perusahaan harus lebih memperhatikan timbal balik bagi pegawai. Hal ini mengingat, dengan pemberian kompensasi maka organisasi atau perusahaan mampu mempertahankan produktivitas. Tanpa kompensasi yang memadai pegawai akan cenderung menurunkan loyalitas kerja terhadap perusahaan yang akan berdampak langsung pada kinerja individu. Dengan demikian, balas jasa atas hasil pekerjaan yang telah dilaksanaan apabila telah mencapai atau melebihi target merupakan poin penting dalam mempertahankan loyalitas serta meningkatkan kinerja individunya. (3) pada variabel loyalitas karyawan perusahaan, sebaiknya memberikan ruang gerak bagi pegawai untuk belajar dan mengembangkan diri karena hal ini akan mengasah kemampuan dan keterampilan pegawai yang nantinya akan berdampak baik bagi perusahaan.

Saran bagi penelitian selanjutnya, yang melakukan penelitian di objek yang sama akan lebih baik lagi jika memperluas sampel penelitian dan dapat meneliti disemua departemen yang ada di PT PLN (Persero) Unit Induk Distribusi Jateng dan DI Yogyakarta kantor Semarang. Penelitian selanjutnya diharapkan dapat menambahkan variabel-variabel lain untuk menguji loyalitas pegawai serta dapat dilakukan pada objek yang berbeda agar dapat dijadikan perbandingan. Peneliti juga menyarankan agar penelitian selanjutnya untuk menggunakan metode penelitian yang berbeda.

\section{DAFTAR PUSTAKA}

A.A Anwar Prabu Mangkunegara 2008. Manajemen Sumber Daya Manusia, cetakan kelima, Penerbit PT. Remaja Rosdakarya. Bandung.

Abdullah, M. 2014. Manajemen dan Evaluasi Kinerja Karyawan. Yogyakarta : Penerbit Aswaja Pressindo.

Abdurrahmat Fathoni. 2006.Manajemen Sumber Daya Manusia, Bandung : Rineka Cipta.

Achmad S. Rucky. (2010). Sistem Manajemen Kinerja. Bumi Aksara, Jakarta

Agus Tunggul Saputra. (2016). Pengaruh Kepuasan Kerja dan Loyalitas Terhadap Kinerja Karyawan PT Sun Stra Motor Cabang Negara. Universitas Pendidikan Ganesha Singaraja, Indonesia.

Ambar T. Sulistiyani dn Rosidah. 2003. Manajemen Sumber Daya Manusia. Cetakan Pertama. Penerbit Graha Ilmu. Yogyakarta.

Andrew M.C. Mamesah. (2016).Pengaruh Lingkungan Kerja, Disiplin Kerja, dan Loyalitas Kerja Terhadap Kinerja Karyawan Pada LPP RRI Manado.JurnalUniversitas Sam Ratulangi Manado

Anwar Basalamah. (2012). Pengaruh Kepuasan Kerja Terhadap Loyalitas Staf Reception Pada Hotel X Di Madiun Jawa Timur.JurnalBINUS University.

B. Siswanto Sastrohadiwiryo. 2002. Manajemen Tenaga Kerja Indonesia Pendekatan Administrasi dan Operasional. Jakarta : Bumi Aksara 
Bangun, Wilson. 2012. “Manajemen Sumber Daya Manusia”. Jakarta: Erlangga.

Bilson Simamora. 2002.Panduan Riset Perilaku Konsumen. Surabaya: Pustaka Utama.

Filian Mufcha Ihwana. (2017). Pengaruh Kompensasi Dan Motivasi Kerja Terhadap Loyalitas Perawat Magang Pada Rumah Sakit Lanud Iswahjudi Maospati Kab. Magetan.JurnalUniversitas PGRI Madiun.

Gauzali Saydam. (2005). Manajemen Sumberdaya Manusia: Suatu pendekatan Mikro. Jakarta: Djambaran.

Hadari Nawawi. 2005. Penelitian Terapan.YogyakartaGajah Mada University Press.

Handoko, T H. 2004. Manajemen Personalia dan Sumberdaya Manusia. BPFE, Yogyakarta.

Hasibuan, M. 2003. Organisasi dan Motivasi Dasar Peningkatan Produktivitas. Jakarta : PT.Bumi Aksara.

Hasibuan, Malayu. S.P. 2008. Manajemen Dasar, Pengerian, Dan Masalah. Jakarta: PT Bumi Aksara.

Indra Ardianto. (2016).Pengaruh Beban Kerja dan Lingkungan Kerja Terhadap Loyalitas Karyawan PD. BPR Bank Daerah Karang Anyar.JurnalFakultas Ekonomi UNSA.

Leonardo Endrick, Fransisca Andreani (2015). Pengaruh Pemberian Kompensasi Terhadap Kinerja Karyawan Pada PT. Kopanitia

Marpaung, Rio. 2012.Pengaruh Kecerdasan Emosional Pemimpin Terhadap Kinerja dan Loyalitas Karyawan. Fakultas Ekonomi. Universitas Riau.

Ni Made Rima Pranita. 2016. Pengaruh Loyalitas Pegawai Terhadap Kinerja Lembaga Perkreditan Pada LPD Desa Adat Kedonganan. Universitas Udayana, Bali.

Putu Meidita Larastrini. 2019. Pengaruh Kepuasan Kerja, Lingkungan Kerja dan Work Life Balance Terhadap Loyalitas Karyawan Pada Rumah Sakit Umum Puri Raharja. Universitas Udayana, Bali, Indonesia.

Rahmadana Safitri. 2015. PengaruhKompensasi Terhadap Loyalitas Karyawan PT Putera Lautan Kumala Lines Samarinda. Universitas Mulawarman.

Robbins, P. Stephen. (2006). Perilaku Organisasi. Edisi kesepuluh. Jakarta: PT Indeks Kelompok Gramedia

Sudimin, Theo. (2003). Whistleblowing: Dilema Loyalitas dan Tanggung Jawab Public. Manajemen \& Usahawan Indonesia. Jakatra : Gramedia Jakarta Utama.

Supriyanto, Achamd Sani dan Mashuri Machfudz. 2010. Metodologi Riset Manajemen Sumber Daya Manusia. Malang: UIN MALIKI Press.

Veithzal Rivai dan Ella Sagala.(2013). Manajemen Sumber Daya Manusia untuk Perusahaan, Rajawali pers, Jakarta.

Veithzal Rivai. (2011). Manajemen Sumber Daya Manusia. Edisi Keempat. Jakarta : PT. Raja Gafindo.

Yunuarsih, Tjutju, dan Suwatno. (2011). Manajemen Sumber Daya Manusia. Bandung : Alfabeta 